Pengaruh Blended Learning Berbasis Jejaring Sosial Edmodo pada Model Discovery Learning terhadap Hasil Belajar Peserta Didik Kelas XI MIPA SMA Negeri I5 Makassar (Studi pada Materi Pokok Larutan Penyangga)

\title{
Pengaruh Blended Learning Berbasis Jejaring Sosial Edmodo pada Model Discovery Learning terhadap Hasil Belajar Peserta Didik (Studi pada Materi Pokok Larutan Penyangga)
}

\section{The Effect of Blended Learning Based on Edmodo Social Network at Discovery Learning Models toward Learning Achievement of Students (Study of Buffer Solution)}

\author{
${ }^{1)}$ Musdalifa, ${ }^{2)}$ Ramdani, ${ }^{3)}$ Muhammad Danial \\ ${ }^{123)}$ Jurusan Kimia Fakultas Matematika dan Ilmu Pengetahuan Alam \\ Universitas Negeri Makassar, Jl. Dg Tata Raya Makassar, Makassar 90224 \\ Email:musda2709@gmail.com
}

\begin{abstract}
ABSTRAK
Penelitian ini merupakan penelitian eksperimen semu yang bertujuan untuk mengetahui pengaruh blended learning berbasis jejaring sosial edmodo pada model discovery learning terhadap hasil belajar peserta didik kelas XI MIPA SMA Negeri 15 Makassar pada materi larutan penyangga. Desain penelitian yang digunakan adalah posttest only control group design. Populasi dalam penelitian ini adalah peserta didik kelas XI MIPA SMA Negeri 15 Makassar yang terdiri dari lima kelas. Pengambilan sampel dilakukan secara random sampling. Kelompok eksperimen yaitu kelas XI MIPA 2 dan kelompok kontrol yaitu kelas XI MIPA. Berdasarkan hasil analisis deskriptif diperoleh rata-rata hasil belajar kelompok eksperimen 76,61 lebih tinggi dari kelompok kontrol yaitu 74,00. Hasil analisis statistik inferensial terhadap hasil belajar peserta didik menunjukkan bahwa data pada kelompok ekperimen dan kelompok kontrol terdistribusi normal serta berasal dari populasi yang homogen. Uji hipotesis menggunakan uji-t. diperoleh $t_{\text {hitung }}>t_{\text {tabel }}(3,47>$ 2,01) sehingga $\mathrm{H}_{0}$ ditolak dan $\mathrm{H}_{1}$ diterima. Ada pengaruh blended learning berbasis jejaring sosial edmodo dengan model discovery learning terhadap hasil belajar peserta didik kelas XI MIPA SMA Negeri 15 Makassar pada materi larutan penyangga.
\end{abstract}

Kata kunci: Edmodo, discovery learning, dan hasil belajar.

\section{ABSTRACT}

This study is a quasi-experimental study that aims to determine the effect of blended learning based on edmodo social network at discovery learning models toward learning achievement of students class XI MIPA SMAN 15 Makassar at buffer solution subject matter. The research design is the posttest only control group design. The population in this study are the students of classes XI MIPA SMAN 15 Makassar which consists of five classes. Sampling is done by random sampling. The experimental group is XI MIPA 2 and the control group is XI MIPA 1. 
Pengaruh Blended Learning Berbasis Jejaring Sosial Edmodo pada Model Discovery Learning terhadap Hasil Belajar Peserta Didik Kelas XI MIPA SMA Negeri I5 Makassar (Studi pada Materi Pokok Larutan Penyangga)

Based on the results of descriptive analysis, the average of learning achievement of experimental group is 76.61 that higher than in the control group that is 74.00 . The results of inferential statistical analysis toward learning achievement indicate that the data on the experimental group and the control group are normal distribution and homogenous. Hypothesis testing using t-test obtained tcount $>$ ttable $(3.47>2.01)$ so that Ho rejected and $\mathrm{H} 1$ accepted. There is an effect of blended learning based on edmodo social network at discovery learning models toward learning achievement of students class XI MIPA SMAN 15 Makassar at buffer solution subject matter.

Keywords: Edmodo, discovery learning, and learning achievement

\section{PENDAHULUAN}

Model pembelajaran discovery learning merupakan salah satu model pembelajaran yang disarankan dalam kurikulum 2013. Model discovery learning lebih menekankan pada penemuan konsep atau prinsip yang sebelumnya belum diketahui. Discovery Learning merupakan rangkaian kegiatan pembelajaran yang melibatkan secara maksimal seluruh kemampuan peserta didik untuk mencari informasi dan menyelidiki secara sistematis, kritis, dan logis agar mereka dapat menemukan pengetahuannya sendiri. Hal ini dapat membutuhkan rasa ingin tahu yang besar dan kesiapan mental dari peserta didik.

Berdasarkan hasil observasi yang dilakukan terhadap salah satu guru mata pelajaran kimia di SMA Negeri 15 Makassar yang telah menerapkan model discovery learning, diketahui bahwa dalam proses pelaksanaan model discovery learning masih berjalan kurang maksimal. Ini dikarekanakan kondisi dan sistem yang belum mendukung untuk melakukan penemuan sendiri. Secara realitis peserta didik didominasi dengan menerima materi secara langsung dari guru. Selain itu, hal ini juga disebabkan karena adanya keterbatasan waktu belajar di kelas sementara peserta didik membutuhkan waktu yang lama untuk menemukan teori atau pemecahan dari suatu masalah. Akibatnya peserta didik belum mampu menemukan konsep dari teori namun waktu tatap muka di kelas telah selesai. Hal ini berdampak pada rendahnya hasil belajar peserta didik.

Blended learning merupakan suatu istilah yang digunakan untuk menggambarkan proses pembelajaran yang mencoba menggabungkan pembelajaran tatap muka dengan pembelajaran online. Blended learning juga diartikan sebagai pencampuran antara berbasis teknologi (online) dan pertemuan tatap muka (face-to-face meeting) dalam suatu aktivitas pembelajaran. Hal ini menunjukkan bahwa blended learning dapat digunakan sebagai upaya untuk mengatasi adanya keterbatasan waktu pembelajaran tatap muka di kelas.

Salah satu materi kimia yang memerlukan pemahaman konsep secara mendalam dan cakupan materi 
Pengaruh Blended Learning Berbasis Jejaring Sosial Edmodo pada Model Discovery Learning terhadap Hasil Belajar Peserta Didik Kelas XI MIPA SMA Negeri I5 Makassar (Studi pada Materi Pokok Larutan Penyangga)

yang luas adalah larutan penyangga. Dalam materi larutan penyangga peserta didik dituntut untuk memahami setiap perbedaan konsep dan karakteristik senyawa yang terlibat dalam pembentukan larutan penyangga. Pemecahan permasalahan pada materi larutan penyangga menuntut peserta didik lebih kreatif dan inovatif. Hal tersebut menyebabkan perlunya metode dan model yang sesuai dalam proses pembelajaran.

Adapun di sisi lain, hasil observasi terhadap peserta didik kelas XI MIPA SMA Negeri 15 Makassar diperoleh data bahwa sebagian besar peserta didik memiliki handphone dengan sistem operasi android. Perkembangan teknologi dengan berbagai software yang tersedia pada zaman modern ini memberikan kemudahan untuk mengakses media pembelajaran. Namun, peserta didik belum mampu memaksimalkan hal tersebut. Peserta didik lebih senang membuka internet untuk mengakses jejaring sosial.

Adanya perkembangan teknologi tersebut menunjukkan bahwa salah satu media yang dapat digunakan guru agar proses pembelajaran dapat berlangsung menyenangkan, menarik perhatian, dan melibatkan peserta didik secara aktif adalah media berbasis jejaring sosial. Oleh karena itu, peserta didik dapat mengoptimalkan penggunaan teknologi berbasis jejaring sosial untuk tujuan pendidikan. Salah satu jejaring sosial yang dapat digunakan dalam proses pembelajaran adalah edmodo. Edmodo merupakan salah satu media berbasis jejaring sosial yang mirip dengan facebook dan di dalamnya terdapat berbagai konten untuk pendidikan (Istiqomah dan Ninik, 2013; Sudibjo dan Wasis, 2013; Setyono, 2015).

Edmodo menyediakan berbagai fitur untuk terhubung dan berkolaborasi antara peserta didik dan guru dalam berbagi konten pendidikan, mengelola tugas, dan menangani pemberitahuan setiap aktivitas dengan cara yang aman dan mudah (Putranti, 2013 dan Nu'man 2014). Edmodo membantu guru membangun kelas virtual (kelas maya) sesuai dengan kondisi belajar di dalam kelas yang berdasarkan pada pembagian kelas nyata di sekolah. Selain itu, penggunaan jejaring sosial edmodo juga mampu membatu peserta didik memahami materi larutan penyangga. Hal ini dikarenakan jejaring sosial edmodo mampu memvisualisasikan materi larutan penyangga dalam bentuk video dan gambar sehingga peserta didik lebih mudah memahaminya.

Pelaksanaan

proses

pembelajaran dengan memanfaatkan media edmodo secara kontinyu dapat menumbuhkan jiwa kompetitif peserta didik karena masing-masing dari kelompok belajar akan menampilkan berbagai keuggulannya sehingga terciptalah pendidikan yang berkualitas secara terus-menerus. Hasil penelitian yang dilakukan oleh Sudibjo dan Wasis (2013) terkait penggunaan media pembelajaran fisika dengan elearning berbasis edmodo blog education mengungkapkan bahwa pembelajaran dengan e-learning 
Pengaruh Blended Learning Berbasis Jejaring Sosial Edmodo pada Model Discovery Learning terhadap Hasil Belajar Peserta Didik Kelas XI MIPA SMA Negeri I5 Makassar (Studi pada Materi Pokok Larutan Penyangga)

berbasis edmodo blog education membantu peserta didik dalam meningkatkan nilai kognitifnya. Penelitian yang dilakukan oleh Sumianing, Hari, dan Haryono (2017) juga mengungkapkan bahwa berdasarkan hasil analisis ketuntasan belajar peserta didik terdapat pengaruh yang signifikan terhadap rata-rata hasil belajar kelas X SMA Negeri 1 Jepara dengan menggunakan model pembeljaran discovery learning dengan bantuan media e-learning edmodo.

Berdasarkan latar belakang di atas dilakukan penelitian terkait pengaruh blended learning berbasis jejaring sosial edmodo pada model pembelarajan discovery learning terhadap hasil belajar peserta didik kelas XI MIPA SMA Negeri 15 Makassar pada materi larutan penyangga.

\section{METODE PENELITIAN}

Penelitian ini merupakan jenis penelitian quasi experimental. Variabel bebas dalam penelitian ini adalah blended learning berbasis jejaring sosial edmodo pada model discovery learning dan model discovery learning tanpa menggunakan blended learning berbasis jejaring sosial edmodo. Adapun variabel terikatnya adalah hasil belajar peserta didik kelas XI MIPA SMAN 15 Makassar. Adapun Desain penelitian yang digunakan adalah posttest-only control design. Desain ini dipilih karena disesuaikan dengan tujuan penelitian yaitu untuk mengetahui ada atau tidaknya pengaruh penggunaan jejaring sosial edmodo dalam pembelajaran kimia dengan model discovery learning terhadap hasil belajar peserta didik (Sugiyono, 2015).

Populasi dalam penelitian ini adalah seluruh peserta didik kelas XI MIPA SMAN 15 Makassar tahun pelajaran 2018/2019 yang terdiri dari lima kelas yaitu kelas XI MIPA 1 sampai kelas MIPA 5. Adapun Teknik pengambilan sampel dalam penelitian ini adalah teknik simple random sampling yaitu pengambilan kelompok sampel dari populasi secara acak. Dari lima kelas yang menjadi populasi penelitian terpilih dua kelas secara acak sebagai kelas sampel penelitian. Kelas XI MIPA 1 sebagai kelompok kontrol dan kelas XI MIPA 2 sebagai kelompok eksperimen. Instrumen yang digunakan pada penelitian ini adalah tes hasil belajar kimia, lembar observasi keterlaksanaan pembelajaran dan aktivitas belajar peserta didik. Lembar observasi keterlaksanaan pembelajaran dan aktivitas belajar peserta didik.

Teknik analisis data yang digunakan adalah analisis statistik deskriptif dan analisis statistik inferensial. Statistik deskriptif meliputi penyajian tabel, diagram, nilai ratarata, nilai tertinggi, nilai terendah, dan standar deviasi. Untuk mengetahui nilai yang diperoleh siswa, maka skor diubah ke nilai dengan menggunakan rumus:

Nilai $=($ skor yang diperoleh siswa/skor maksimum) x 100

Nilai yang diperoleh peserta didik dapat dikategorikan tuntas dan tidak tuntas. Pengelompokan tingkat 
ketuntasan belajar peserta didik dalam memahami materi kimia pada kategori tuntas atau tidak tuntas berdasarkan acuan KKM yang ditentukan SMAN 15 Makassar pada Tabel 1.

Tabel 1. Klasifikasi Ketuntasan Belajar Peserta Didik SMA Negeri 15 Makassar Tahun Pelajaran 2018/2019

\begin{tabular}{cc} 
Nilai & Kategori \\
\hline$\geq 75$ & Tuntas \\
\hline$<75$ & Tidak Tuntas \\
\hline (Sumber
\end{tabular}

(Sumber: SMAN 15 Makassar)

Statistik inferensial yang digunakan untuk menguji hipotesis adalah uji - t. Sebelum dilakukan uji hipotesis terlebih dahulu dilakukan uji prasyarat yaitu uji normalitas dan uji homogenitas. Uji hipotesis digunakan untuk menguji hipotesis yang telah dirumuskan. Pengujian hipotesis dilakukan dengan uji satu pihak.

$$
\mathrm{H}_{0}: \mu_{1} \leq \mu_{2} \quad \mathrm{H}_{1}: \mu_{1}>\mu_{2}
$$

Dimana,

$\mu_{1}=$ rata- rata nilai posttest kelompok eksperimen $\mu_{2}=$ rata- rata nilai posttestkelompok kontrol

$\mathrm{H}_{0}=$ Tidak ada pengaruh blended learning berbasis jejarig sosial edmodo pada model discovery learning terhadap hasil belajar peserta didik kelas XI MIPA SMAN 15 Makassar pada materi pokok larutan penyangga.

$\mathrm{H}_{1}=$ Ada pengaruh blended learning berbasis jejarig sosial edmodo pada model discovery learning terhadap hasil belajar peserta didik kelas XI MIPA SMAN 15 Makassar pada materi pokok larutan penyangga.

Pengujian yang digunakan adalah uji-t dengan $\alpha=0,05$

$$
\mathrm{t}_{\text {hitung }}=\frac{\overline{\mathrm{X}}_{1}-\overline{\mathrm{X}}_{2}}{\mathrm{dsg} \sqrt{\frac{1}{\mathrm{n}_{1}}+\frac{1}{\mathrm{n}_{2}}}}
$$

\section{HASIL DAN PEMBAHASAN}

\section{A. Hasil Penelitian}

Analisis statistik deskriptif memberikan gambaran umum mengenai karakteristik pencapaian hasil belajar di SMA Negeri 15 Makassar untuk materi larutan penyangga pada kelompok eksperimen dan kelompok kontrol. Diperoleh hasil belajar peserta didik yang diperoleh pada Tabel 2.

Tabel 2. Hasil Analisis Statistik Deskriptif Hasil Belajar pada Kelompok Eksperimen dan Kelompok Kontrol

\begin{tabular}{cccc}
\hline \multirow{2}{*}{ No. } & Statistik & Nelompok Eksperimen & $\begin{array}{c}\text { Kelompok } \\
\text { Kontrol }\end{array}$ \\
\cline { 3 - 4 } & & 27 & 27 \\
\hline 1. & Jumlah Siswa & 90 & 90 \\
\hline 2. & Nilai Tertinggi & 55 & 50 \\
\hline 3. & Nilai Terendah & 76,61 & 74,00 \\
\hline 4. & Nilai Rata-rata & 85,16 & 71,00 \\
\hline 5. & Modus (Mo) & 9,27 & 10,96 \\
\hline 6. & Standar Deviasi & &
\end{tabular}


Berdasarkan hasil observasi yang dilakukan pada kelompok eksperimen maupun kelompok kontrol, diperoleh persentasi aktivitas belajar peserta didik yang dapat dilihat pada Tabel 3 .

Uji normalitas hasil belajar pada kelompok eksperimen diperoleh $\chi_{\text {hitung }}^{2}=5,045$. Nilai untuk $\chi_{\text {tabel }}^{2}$ pada taraf kepercayaan $(\alpha)=0,05$ dan derajat kebebasan $(d k)=3$ diperoleh nilai $\chi_{\text {tabel }}^{2}=7,815$. Nilai $\chi_{\text {hitung }}^{2}<$ $\chi_{\text {tabel }}^{2}$ maka disimpulkan bahwa data peningkatan hasil belajar pada kelompok eksperimen terdistribusi normal. Sedangkan untuk kelompok kontrol diperoleh nilai $\chi^{2}$ hitung $=7,052$. Untuk $\chi_{\text {tabel }}^{2}$ pada taraf kepercayaan 0,05 dan derajat kebebasan $(d k)=3$ diperoleh $\chi_{\text {tabel }}^{2}=7,815$. Nilai $\chi^{2}$ hitung $<\chi^{2}$ tabel maka disimpulkan bahwa data peningkatan hasil belajar pada kelompok kontrol terdistribusi normal.

Berdasarkan hasil uji homogenitas diperoleh nilai $F_{\text {hitung }}=$
1,40 dan nilai dari $F_{\text {tabel }}$ pada taraf kepercayaan 0.05 sebesar 1,93. Nilai $F_{\text {hitung }}<F_{\text {tabel }}$ disimpulkan bahwa varians antara kelompok eksperimen dan kelompok kontrol berasal dari populasi yang homogen.

Pengujian hipotesis dilakukan menggunakan statistik parametrik (ujit). Berdasarkan perhitungan hasil belajar peserta didik menggunakan uji$\mathrm{t}$, diperoleh $\mathrm{t}_{\text {hitung }}$ sebesar 3,47 dan nilait $_{\text {tabel }}$ pada tarafsignifikansi 0,05 dan $\mathrm{dk}=52$ sebesar 2,01 yang berarti, nilai $\mathrm{t}_{\text {hitung }}>\mathrm{t}_{\text {tabel }}(3,47>2,01)$. Hal ini menunjukkan bahwa $H_{o}$ ditolak dan $H_{l}$ diterima. Dapat disimpulkan bahwa ada pengaruh penggunaan blended learning berbasis jejaring sosial edmodo dalam pembelajaran kimia melalui model discovery learning terhadap hasil belajar peserta didik kelas XI MIPA SMAN 15 Makassar pada materi pokok larutan penyangga.

Tabel 3. Hasil Persentasi Aktivitas Belajar Peserta Didik

\begin{tabular}{|c|c|c|c|c|c|c|}
\hline \multirow{2}{*}{ No. } & \multirow{2}{*}{ Kegiatan } & \multirow{2}{*}{ Tahap } & \multicolumn{4}{|c|}{ Persentase (\%) } \\
\hline & & & Eksperimen & Ket. & Kontrol & Ket. \\
\hline 1. & Pendahuluan & & 90,97 & $\begin{array}{c}\text { Sangat } \\
\text { baik }\end{array}$ & 88,66 & $\begin{array}{c}\text { Sangat } \\
\text { baik }\end{array}$ \\
\hline 2. & & $\begin{array}{c}\text { Stimulation } \\
\text { (Stimulasi/ } \\
\text { pemberian } \\
\text { rangsangan) }\end{array}$ & 86,42 & $\begin{array}{c}\text { Sangat } \\
\text { baik }\end{array}$ & 75,62 & Baik \\
\hline 3. & Inti & $\begin{array}{c}\text { Problem } \\
\text { statement } \\
\text { (pernyataan/ } \\
\text { identifikasi } \\
\text { masalah) }\end{array}$ & 78,70 & Baik & 72,05 & Baik \\
\hline 4. & & Data & 85,19 & Sangat & 73.15 & Baik \\
\hline
\end{tabular}




\begin{tabular}{|c|c|c|c|c|c|c|}
\hline \multirow{2}{*}{ No. } & \multirow{2}{*}{ Kegiatan } & \multirow{2}{*}{ Tahap } & \multicolumn{4}{|c|}{ Persentase (\%) } \\
\hline & & & Eksperimen & Ket. & Kontrol & Ket. \\
\hline & & $\begin{array}{c}\text { collection } \\
\text { (Pengumpulan } \\
\text { Data) }\end{array}$ & & baik & & \\
\hline 5. & & $\begin{array}{c}\text { Data } \\
\text { Processing } \\
\text { (Pengolahan } \\
\text { Data) }\end{array}$ & 79,63 & Baik & 76.85 & Baik \\
\hline 6. & & $\begin{array}{l}\text { Verification } \\
\text { (Pembuktian) }\end{array}$ & 66,67 & Baik & 62,04 & Baik \\
\hline 7. & & $\begin{array}{c}\text { Generalization } \\
\text { (menarik } \\
\text { kesimpulan/ } \\
\text { generalisasi) }\end{array}$ & 72,69 & Baik & 68,98 & Baik \\
\hline 8. & Penutup & & 95,37 & $\begin{array}{c}\text { Sangat } \\
\text { baik }\end{array}$ & 91,67 & $\begin{array}{c}\text { Sanga } \\
\text { baik }\end{array}$ \\
\hline & Rata & & 82,29 & & 79,67 & \\
\hline
\end{tabular}

\section{B. Pembahasan}

Penelitian ini dilakukan untuk mengetahui ada tidaknya pengaruh penggunaan blended learning berbasis jejaring sosial edmodo dalam pembelajaran kimia melalui model discovery learning terhadap hasil belajar peserta didik XI MIPA SMAN 15 Makassar pada materi pokok larutan penyangga. Edmodo merupakan sebuah situs jejaring sosial yang dirancang khusus untuk tujuan pendidikan, memiliki kemiripan dengan jejaring sosial facebook, dan dapat diakses secara gratis melalui situs www.edmodo.com. Hasil analisis statistik deskriptif pada Tabel 2 menunjukkan bahwa nilai rata-rata kelompok eksperimen lebih tinggi dibandingkan nilai rata-rata pada kelompok kontrol. Perbedaan nilai rata-rata yang diperoleh disebabkan karena adanya perbedaan perlakuan pada kedua kelompok sampel penelitian tersebut. Kelompok eksperimen menggunakan blended learning berbasis jejaring sosial edmodo sedangkan pada kelompok kontrol tidak menggunakan blended learning berbasis jejaring sosial edmodo, namun dengan model pembelajaran yang sama yaitu model discovery learning.

Data hasil belajar peserta didik yang sering muncul (modus) pada kelompok eksperimen lebih tinggi dibandingkan pada kelompok kontrol. Hal ini menunjukkan bahwa peserta

didik pada kelompok eksperimen lebih banyak yang memperoleh nilai lebih 
Pengaruh Blended Learning Berbasis Jejaring Sosial Edmodo pada Model Discovery Learning terhadap Hasil Belajar Peserta Didik Kelas XI MIPA SMA Negeri I5 Makassar (Studi pada Materi Pokok Larutan Penyangga)

tinggi dibandingkan dengan kelompok kontrol. Selain itu, terdapat pula perbedaan pada nilai standar deviasi, kelompok ekperimen memperoleh nilai standar deviasi yang lebih rendah dibandingkan pada kelompok kontrol. Hal ini berarti penyimpangan data pada kelompok eksperimen dengan menggunakan blended learning berbasis jejaring sosial edmodo melalui model discovery learining lebih sedikit dibandingkan dengan kelompok kontrol tanpa menggunakan blended learning berbasis jejaring sosial edmodo melalui model discovery learining.

Kebenaran dari hipotesis dibuktikan melalui pengujian hipotesis. Namun sebelum melakukan uji hipotesis, terlebih dahulu dilakukan uji prasyarat yakni uji normalitas dan homogenitas. Berdasarkan pengujian analisis prasyarat (uji normalitas dan uji homogenitas), dinyatakan bahwa data dari kelompok eksperimen dan kontrol berasal dari populasi yang terdistribusi normal dan kedua kelompok berasal dari varians yang homogen. Oleh karena itu, pengujian hipotesis dilakukan dengan menggunakan uji parsial atau uji-t. Hasil pengujian hipotesis dengan menggunakan uji-t diperoleh $t_{\text {hitung }}=$ 3,47 dan nilai $t_{\text {tabel }}$ pada taraf signifikan 0,05 dan $\mathrm{dk}=52$ sebesar 2,01 . Hal tersebut menunjukkan bahwa nilai $t_{\text {hitung }}>t_{\text {tabel }}(3,47>2,01)$ yang berarti $\mathrm{H}_{0}$ ditolak dan $\mathrm{H}_{1}$ diterima atau dengan kata lain hipotesis yang daijukan diterima. Hasil belajar peserta didik pada kelompok eksperimen yang dibelajarkan dengan menggunakan blended learning berbasis jejaring sosial edmodo pada model pembelajaran discovery learning lebih tinngi daripada hasil belajar peserta didik yang dibelajarkan tanpa menggunakan blended learning berbasis jejaring sosial edmodo pada model pembelajaran discovery learning. Hal tersebut disebabkan karena pembelajaran berbasis jejaring sosial edmodo dapat menciptakan proses belajar yang menarik, inovatif dan efektif (Al Said, 2015).

Karakter materi larutan penyangga yang memerlukan pemahaman konsep (pada bagiam sifat larutan penyangga), matematis (pada bagian perhitungan $\mathrm{pH}$ larutan penyangga), dan aplikatif (pada bagian fungsi larutan penyangga) membuat peserta didik kesulitan dalam mempelajari materi tersebut. Adanya penggunaan blended learning berbasis jejaring sosial edmodo yang dibelajarkan pada materi larutan penyangga membantu peserta didik memahami materi tersebut. Ini dikarenakan penggunaan blended learning berbasis jejaring sosial edmodo mampu memvisualisasikan materi larutan penyangga dalam bentuk video dan gambar sehingga peserta didik lebih mudah memahaminya. Hal tersebut didukung oleh penelitian Afdhila, dkk. (2017) tentang penerapan pembelajaran blended learning pada materi larutan penyangga di SMAN 1 Unggul Darul Imarah yang menyatakan bahwa ketuntasan belajar peserta didik dengan menerapkan blended learning pada materi larutan penyangga dikategorikan sangat baik. 
Berdasarkan faktor-faktor yang mempengaruhi hasil belajar diketahui bahwa blended learning berbasis jejaring sosial edmodo memberikan pengaruh secara eksternal maupun internal. Blended learning berbasis jejaring sosial edmodo dapat digunakan sebagai media pembelajaran di kelas yang mampu menarik perhatian peserta didik sehingga peserta didik lebih terlibat dalam proses pembelajaran. Hal ini dapat dilihat berdasarkan Tabel 3 . yang menunjukkan bahwa kelompok eksperimen yang dibelajarkan dengan menggunakan blended learning berbasis jejaring sosial edmodo pada model discovery learning memiliki presentase aktivitas peserta didik yang lebih tinggi dibandingkan dengan kelompok kontrol tanpa menggunakan blended learning berbasis jejaring sosial edmodo pada model discovery learning.

Berdasarkan Tabel 3 juga diketahui bahwa presentase aktivitas belajar peserta didik pada tiap tahap untuk kelompok eksperimen lebih tinggi dibandingkan kelompok kontrol.

Ini sesuai dengan penelitian yang dilakukan Sandi (2012) yang mengungkapkan bahwa penggunaan blended learning mendorong peserta didik untuk aktif dalam mengikuti proses pembelajaran. Namun, kelemahan dari penggunaan blended learning berbasis jejaring sosial edmodo yaitu estimasi waktu yang digunakan peserta didik ketika belajar di luar kelas tatap muka tidak dapat diketahui.
Hal tersebut menunjukkan bahwa penggunaan blended learning berbasis jejaring sosial edmodo pada model discovery learning mampu memberikan pengaruh positif terhadap hasil beljar peserta didik pada kelompok eksperimen dibandingkan dengan kelompok kontrol tanpa menggunakan blended learning berbasis jejaring sosial edmodo pada model discovery learning untuk materi larutan penyangga. Hal ini sesuai dengan penelitian Sumianing, Hari, dan Haryono (2017), Setyono (2015), Mamentu (2013), dan Herlambank (2015), yang menyatakan bahwa media jejaring sosial edmodo memberikan dampak positif hasil belajar peserta didik.

Berdasarkan uji hipotesis yang telah dilakukan dalam penelitian ini, maka dapat disimpulkan bahwa penggunaan blended learning berbasis jejaring sosial edmodo dalam pembelajaran kimia pada model discovery learning berpengaruh positif terhadap hasil belajar peserta didik kelas XI MIPA SMAN 15 Makassar pada materi pokok larutan penyangga.

\section{KESIMPULAN DAN SARAN}

\section{A. Kesimpulan}

Berdasarkan hasil analisis data dan pembahasan maka dapat disimpulkan bahwa terdapat pengaruh penggunaan blended learning berbasis jejaring sosial edmodo pada model discovery learning terhadap hasil belajar peserta didik kelas XI MIPA SMAN 15 Makassar pada materi pokok larutan penyangga. 


\section{B. Saran}

Berdasarkan hasil penelitian ini yang sudah dilakukan, maka peneliti mengajukan beberapa saran sebagai berikut :

1. Proses identifikasi masalah pada penelitian ini masih dilakukan dengan cara menuliskan rumusan masalah yang diperoleh pada lembar kerrja peserta didik (LKPD), namun bagi peneliti selanjutnya dapat menggunakan kolom komentar pada akun jejaring sosial edmodo untuk menuliskan rumusan masalah sehingga peserta didik lebih interaktif.

2. Hal yang harus diperhatikan sebelum melaksanakan blended learning berbasis jejaring sosial edmodo dalam proses pembelajaran yaitu guru sebaiknya terlebih dahulu melakukan simulasi penggunaan akun edmodo sehingga pada penerapannya menjadi lebih efektif di kelas.

\section{DAFTAR PUSTAKA}

Afdhila, Rizqa., Muhammad Nazar, dan Latifah Hanum. 2017. Penerapan Pembelajaran Blended Learning pada Materi Larutan Penyangga di SMA Negeri 1 Unggul Darul Imarah. Jurnal Ilmiah Mahasiswa Pendidikan Kimia (JIMPK). Vol.(2), no. 3.

Al-said, K. M. 2015. Student's Perceptions of Edmodo and Mobile Learning and their Real Barriers towards them. The Turkish online Jurnal of
Educationnal Technology (TOJET). Vol (14), no. 2.

Istiqomah, Sri Banun Titi dan Ninik Azizah. 2013. Penerapan Metode Blended Learning Berbasis ICT untuk Meningkatkan Minat dan Prestasi Belajar pada Mata Kuliah Ilmu Sosial Budaya Dasar (ISBD) di Prodi D-III Kebidanan FIK UNIPDU Jombang. Jurnal Eduhealth. Vol (3), no. 2.

Mamentu, F.Y. 2013. Pengaruh Penggunaan Media Pembelajaran Online Edmodo Terhadap Hasil Belajar Siswa Kelas XI Padaa Mata Pelajaran TIK di SMAN 1 Tondano. Jurnal Engineering dan Education UNIMA. Vol (1), no. 4.

Nu'man, Ahmad Zanin. 2014. Efektifitas Penerapan E-learning Model Edmodo dalam Pembelajaran Pendidikan Agama Islam terhadap Hasil Belajar Siswa. Duta.com. Vol (7), no. 1.

Puranti, Nurita. 2013. Cara Membuat Media Pembelajaran Online Menggunakan Edmodo. Jurnal Pendidikan Informatika dan Sains. Vol (2), no. 2.

Sandi, Gede. 2012. Pengaruh Blended Learning terhadap Hasil Belajar Kimia Ditinjau dari Kemandirian Siswa. Jurnal Pendidikan dan Pengajaran. Vol (45), no. 3.

Setyono, Evin Yudhi. 2015. Pengaruh Penggunaan Media Jejaring Sosial Edmodo terhadap Hasil Belajar Mahasiswa pada Topik Pembuatan Kurva-S Menggunakan Microsoft Excell. Jurnal Sosial dan Humaniora. Vol (5), no. 1. 
Pengaruh Blended Learning Berbasis Jejaring Sosial Edmodo pada Model Discovery Learning terhadap Hasil Belajar

Peserta Didik Kelas XI MIPA SMA Negeri I5 Makassar (Studi pada Materi Pokok Larutan Penyangga)

Sudibjo, Arif dan Wasis. 2013.

Penggunaan Media Pembelajaran

Fisika dengan E-learning

Berbasis Edmodo Blog

Education pada Materi Alat

Optik untuk Meningkatkan

Respons Motivasi dan Hasil

Belajar Siswa di SMP Negeri 4

Surabaya. Jurnal Inovasi

Pendidikan Fisika. Vol (2), no. 3.

Sumianingrum, Ninok Eyiz., Hari

Wibawanto, dan Haryono. 2017.

Efektivitas Metode Discovery

Learning Berbantuan E-Learning

di SMA Negeri 1 Jepara. Jurnal

Ilmu Pendidikan, Keguruan, dan

Pembelajaran. Vol (1), no. 1.

Sugiyono. 2015. Statistika untuk

Penelitian. Bandung: Alfabeta. 